\title{
СТВОРЕННЯ ПАРИЗЬКОЇ КОНСЕРВАТОРІЇ ЯК ВИЗНАЧАЛЬНИЙ ФАКТОР ФОРМУВАННЯ НОВОЇ МУЗИЧНО-ОСВІТНЬОЇ СИСТЕМИ
}

Стаття присвячена питанням корінної перебудови франиузької музично-освітньої системи кіния ХVIII століття на ідейно-політичних засадах революиії 1789 року. Розкриваються ключові напрями розвитку музичного мистецтва, його демократизації на иляху переходу від елітарності до масовості.

Підкреслюється, щуо культурно-ідеологічна антиклерикальна політика револючійного уряду мала вирішальний вплив на процес формування нової музично-освітньої системи країни й відкриття Паризької консерваторії.

3 закриттям метриз, які в дореволюиійний період залишались основними музичними навчальними закладами, виникала потреба заповнити наявну лакуну, котра утворилась в освітньому просторі. I якщзо на першому етапі, в прочесі організації музичної школи Національної гвардії (1792 рік) основні зусилля були спрямовані на підготовку музикантів для військових оркестрів, то на наступних етапах пропонуються розгорнутіші проєкти - заснування Національного музичного інституту (1793 рік) і консерваторії (1795 рік). Головною метою їх створення було формування демократичної національної системи музичної освіти, головним центром якої повинна була стати Паризька консерваторія.

Викладається роль Б. Сарретта й Ф. Госсека у визначенні адміністративно-педагогічної структури навчального закладу й змісту навчання.

Відзначено, щзо навчальний заклад, започаткований на демократичних засадах, забезпечував талановитій молоді незалежно від ї̈ соиіального й економічного статусу безплатний доступ до освіти. Державне фінансування та конкурсна система формування педагогічного й студентського складу стимулювали активізацію творчої конкурениії та сприяли підвищенню рівня професійної майстерності.

Підкреслюеться, щзо заснування Паризької консерваторії стало для Свропи унікальним зразком створення прогресивного музично-освітнього закладу для системної підготовки професійних музикантів.

Новизна дослідження полягає в деталізачії основних сочіально-економічних і політичних факторів та їх впливу на процес формування системи професійної музичної освіти й створення Паризької консерваторії.

Ключові слова: Паризька консерваторія, Велика франиузька револючія, Конвент, музична освіта, мистецчтво, Б. Сарретm.

\author{
Oksana RUDYKA, \\ orcid.org/0000-0002-5484-3607 \\ Graduate Student at the Department of Theory and History of Musical Performance \\ Ukrainian National Tchaikovsky Academy of Music \\ (Kyiv,Ukraine) oksanaflauto@gmail.com
}

\section{FOUNDING OF THE PARIS CONSERVATORY AS A DETERMINING FACTOR FOR THE FORMATION OF A NEW MUSIC EDUCATIONAL SYSTEM}

The article is devoted to the issues of the radical reformation at the end of the 18th century of the French music educational system on the ideological and political basis of the 1789 revolution. The key directions of development of musical art, its democratization on the way of transition from elitism to mass are revealed.

It is emphasized that the Great French Revolution had a decisive influence on the process of forming a new cultural and educational system of the country and on the opening of the Paris Conservatory.

The preconditions for its creation were the anti-clerical policy of the revolutionary government. With the closure of the metriz, which in the pre-revolutionary period remained the main music schools, there was a need to fill the existing gap that was formed in the music-educational space. And if at the first stage, in the process of organizing the music school of the National Guard (1792), the main efforts were aimed at training musicians for military orchestras, then the next stages proposed more detailed projects - the founding of the National Music Institute (1793) and conservatory (1795). The main purpose of their creation was the formation of a democratic national system of music education, the main center of which was to be the Paris Conservatory.

The role of B. Sarrett and F. Gossek in determining the administrative and pedagogical structure of the educational institution and the content of education is highlighted. 
Being founded on a democratic basis, the music educational institution has provided for talented youth open and free access to education on a competitive basis, regardless of social and economic status. State funding and the competitive system of formation of pedagogical and student staff have stimulated the intensification of creative competition and have helped to increase the level of professionalism of artists.

It is noted that the Paris Conservatory foundation was a unique example for Europe to create a progressive musiceducational system for training professional musicians.

The novelty of the research is in the detailed main factors, that the Great French revolution influenced the formation process on the professional music education system and on the Paris Conservatory foundation.

Key words: Paris Conservatory, Great French Revolution, Convention, music education, art, Bernard Sarrette.

Постановка проблеми. Відкриття Паризької консерваторії як головного центру професійної підготовки музикантів стало одним із визначальних факторів, які суттєво вплинули не тільки на розвиток французького музичного мистецтва, але і європейського в цілому. Процес створення навчального закладу (1793-1795 рр.) проходив у період надзвичайно складних умов політичної та економічної нестабільності, спричинених Великою французькою революцією 1789 р., і супроводжувався калейдоскопічною зміною ідеологічних гасел і невизначеністю у формуванні державних інституцій.

Важливою причиною реформи музичної освіти, якої вимагали ідеологи революції, стала потреба постійної участі студентів і педагогів навчальних закладів у забезпеченні музичним супроводом масових маніфестацій і фестивалів, котрі в перші роки революції були основною формою політичних акцій. Проведення глибинних політичних, соціально-економічних і культурних реформ разом 3 антиклерикальними настроями вже на початку докорінної перебудови призвели до ліквідації метриз, котрі впродовж століть залишались основою французької музично-освітньої системи. 3 їх знищенням у культурно-мистецькому просторі з'явилась прогалина, яка вимагала заповнення новими, прогресивнішими формами підготовки професійних музикантів і відкритого доступу до навчання широкому загалу талановитої молоді. Указані питання ще не отримали належного викладення в роботах вітчизняних музикознавців і вимагають детальнішого розкриття на основі документальних джерел. Поява доступу до історіографічних видань Т. Лассабаті й особливо К. П'єра, в котрих зосереджений великий масив історичних документів Паризької консерваторії кінця XVIII-XIX ст., стали основою нашого наукового пошуку й дали можливість детальніше розглянути процес формування нової музично-освітньої системи Франції та передумови створення Паризької консерваторії.

Аналіз останніх досліджень і публікацій. Фундаментальні праці визначних французьких історіографів XIX ст. Т. Ласабаті (Lassabathie,
1860) та К. П'єра (Pierre, 1895, 1900), основою яких стали архівні документи Паризької консерваторії, столичних театрів та оркестрів, продовжують залишатись предметом досліджень вчених, котрі зосереджені на питаннях історії розвитку музичної освіти Франції. Серед останніх робіт, присвячених проблематиці, виділяється дисертація Е. Жарді (Jardin, 2006), в якій розглядається процес формування французьких регіональних консерваторій у ХIX ст., і монографії Д. К. Холомена (Holoman, 2015, 2004), в котрих викладаються етапи становлення Паризької консерваторії та іiі структурних підрозділів. Окремих питань розвитку професійної підготовки скрипалів у Паризькій консерваторії торкається П. Б. Подмазова (2013 р.). Не дивлячись на фундаментальність праць вказаних авторів, визначальні чинники формування нової музично-освітньої системи на ідеологічних засадах Великої французької революції розкрито не в повному обсязі. Саме ширшому їх викладенню присвячена стаття.

Мета статті - визначити основні передумови створення Паризької консерваторії як головного навчального закладу нової музично-освітньої системи Франції в контексті культурної політики Великої французької революції.

Виклад основного матеріалу дослідження. Початок революційних заворушень і перші лозунги, котрі були виголошені на барикадах, дають досить зрозуміле посилання суспільству на відмову від елітарності музичного мистецтва, котре було розраховане на звужене коло королівського двору та його аристократичне оточення. Стрижнем художніх засад формування нової ідеології та культурної політики повинно було стати народне мистецтво для широких мас, а основною концертною естрадою для його вираження - вуличні маніфестації та народні святкування, в яких «ритмічний тріск барабанів здавався народу, який прямував до свободи, єдиною необхідною музикою <...> (Радиге, 1934: 12).

Якщо ще недавно королівські капели й оркестри театрів очолювали кращі європейські музиканти, то в новій реальності для керівництва оркестровим супроводом «голосу народу» обирається 
бухгалтер, син простого шевця, член комітету одного із паризьких районів Бернар Сарретт, який «керувався скоріше громадянським запалом, ніж художніми прагненнями» (Радиге, 1934: 12). Саме на цього, новоспеченого в горнилі перших революційних виступів капітана Національної гвардії, буде покладено не тільки організацію та музичнооркестрове оформлення вуличних маніфестацій, але й значно відповідальнішу місію - формування нової музично-культурної доктрини із чітко визначеною революційною ідеологією, основним спрямуванням якої повинно було стати забезпечення культурних потреб народних мас.

Миттєвий перехід від театральних, симфонічних, вокальних, камерно-інструментальних та інших класичних жанрів академічної музики, котра звучала в Гранд-опері, Італійській опері, королівських палацах та аристократичних салонах для елітарних слухачів, до первинних жанрів народної, революційної пісні, маршу, танцю, які призначались для масового виконання учасниками під час помпезних національних урочистостей $і$ вуличних святкових ходів, не міг не вплинути на музичноконцертну й театральну інфраструктуру Парижа.

3 гіркотою та болем один із поціновувачів характеризує в «Паризькому театральному альманаху» стан славнозвісного театру «Опера», котрий завжди вважався найулюбленішим і найкрасивішим для парижан, а «тепер насправді покинутий...» (Dratwicki, 2002: 297-298).

Ще драматичнішою виявилась доля «Духовних концертів», котрі здебільшого проходили в королівському палаці в Тюїльрі із запрошенням кращих європейських віртуозів. Восени 1789 р. концерти було передано під керівництво Італійського театру, а весною 1790 р. вони припинили своє 65-річне існування. Подібна доля спіткала й менш знаний «Оркестр Олімпійського товариства» ${ }^{1} 3$ професійних виконавців та аматорів, котрий не належав до привілейованих королівських колективів. У липні 1789 р. революційно налаштовані солдати Національної гвардії захопили приміщення товариства та його діяльність була припинена (Bodin, 1984: 95).

Для того, щоб продовжити своє існування, творчі колективи театрів намагаються перелаштувати власну репертуарну політику під революційні гасла, обираючи відповідні лібрето для нових вистав. Аналізуючи їх сюжети, У. Дін вказує на їх нахабну політичну й ідеологічну спрямо-

«Оркестр Олімпійського товариства» був заснований у 1786 р. із метою відновлення концертів аматорів. На замовлення меценатів Й. Гайдн написав для оркестру «Паризьку симфонію» (1786р.). ваність, через що усі три паризькі оперні театри незабаром виплескували на глядачів «потік творів із політичним чи патріотичним посланням» (Dean, 1967-1968: 78).

I якщо театри, змінюючи репертуар, намагались пристосуватись до новосформованої культурної політики революціонерів і таким чином уникнути закриття, то доля музично-освітніх закладів виявилась значно драматичнішою. Найвідчутніший удар був завданий по добре налагодженій системі початкової музичної освіти, котрою опікувалась церква. 18 серпня 1792 р. Конвент прийняв антиклерикальний закон про розпуск метриз ${ }^{2}-$ єдиної мережі безкоштовних шкіл Франції, історія яких налічувала сотні років. У сфері управління церкви й на іiі утриманні перед революцією існувало понад 450 метриз і 15000 музикантів (Maurat, 1925: 3578). Згодом, у листопаді 1793 р., Паризькою комуною було прийнято безпрецедентне рішення про закриття всіх храмів різних віросповідань, які існували в Парижі (Радиге, 1934: 12), i встановлення деїстичного Культу Верховного створіння. Так у короткий час мільйони вірян опинились поза законом ${ }^{3}$, а весь багатотисячний колектив професійних церковних півчих, інструменталістів і вчителів водночас залишився без будь-яких матеріальних засобів існування.

Рівень підготовки церковних виконавців у метризах не завжди відповідав тим критеріям, які висувались до професійних музикантів, особливо в паризьких театрах. Однак перед учнями церковних шкіл і не ставились подібні завдання, головним їх обов'язком було служіння в храмі й вчителювання. 3 метою належної підготовки співаків для королівської опери в 1784 р. (період правління Людовика XVI) було започатковано спеціальний заклад - Королівську школу співу й декламації. Для навчання в цій елітній школі обирались 8 юнаків і 7 дівчат із приємною зовнішністю та фігурою та належними голосовими даними, а перевага надавалась тим, «хто має

\footnotetext{
${ }^{2}$ Метризи існували при католицьких храмах для підготовки церковних півчих із VIII століття. У школу приймались учні 3 6-10 років, котрі впродовж 8-10-річного терміну навчання знаходились на повному утриманні церкви. Крім музичної освіти, яка містила спів, теорію музики й гру на інструментах, юнаки вивчали загальноосвітні предмети (читання, письмо, граматику, арифметику й латинську мову). Обов'язком учнів була участь у всіх церковних службах, весіллях, похоронах, а також у процесіях та інших важливих релігійних урочистостях.

3 Політика дехристиянізації, яка в перше десятиліття революції агресивно проголошувалась і впроваджувалась законодавчо, завдала непоправної шкоди як духовному, так i культурному розвитку Французької республіки. Тільки після приходу до влади Наполеона Бонапарта (1799 р.) були припинені переслідування християн.
} 
голос, $\mathrm{i}$ хто буде не тільки торкатись клавіш клавесина, але хто вміє супроводжувати спів на цьому інструменті <...>» (Pierre, 1900: 3). Очевидно, що встановлені критерії масового відбору учнів для метриз та умови конкурсу до королівської школи суттєво відрізнялись, як і завдання, котрі перед ними ставились, тому кінцевий рівень підготовки випускників не міг бути однаковим.

Через закриття метриз в освітньо-музичному просторі Франції виникла величезна порожнеча, яка вимагала заповнення. «Для заміни цієї застарілої та ретроградної системи революціонери повинні були запропонувати й побудувати більш егалітарний тип освіти» (Jardin, 2006: 24), котрий, 3 однієї сторони, забезпечував би доступність музичної освіти широкому загалу, а з іншої, підіймав якість навчання, яке водночас повинно було залишатись безкоштовним. Закривши церковні школи, Конвент не наважується одночасно припинити діяльність Королівської школи співу й декламації, яка відповідно до перших революційних указів продовжувала тимчасове існування.

Перші кроки на шляху достворення новоїмоделі музичної освіти, вершиною якої стала Паризька консерваторія, на початковому етапі революційних подій виглядають не прогнозованими й хаотичними. Виголошення загальних лозунгів, в яких музика стає одним з основних ідеологічних чинників духу свободи, патріотизму й революційного пориву мас, не супроводжується пропозицією конкретних дій для розв'язання наявних проблем. Здійснені Б. Сарреттом під час організації духового оркестру Національної гвардії заходи, «щоб із досить сильною звучністю акомпанувати голосу Парижа» (Радиге, 1934: 12) в революційних маніфестаціях, а також пошуки необхідних коштів для підтримки його існування фактично були ситуативними й мали локальне значення.

Цілеспрямованішим рухом у напрямі формування початкової музично-освітньої структури нового типу можна вважати такі дії капітана Сарретта. Він із революційним запалом намагається створити школу для юних виконавців на базі оркестру Національної гвардії та досить швидко досягає поставленої мети. Після певних бюрократичних процедур заклад було офіційно відкрито 9 червня 1792 р. Відповідно до прийнятого указу загальна кількість учнів, котрі навчались безкоштовно, становила 120 «<..> молодих людей, синів громадян, які служать у Національній гвардіiі, віком від десяти до шістнадцяти років для тих, хто досі не мав поняття про музику, й віком від вісімнадцяти до двадцяти років для тих, хто вже $\epsilon$ музикантами» (Pierre, 1900: 83).
Судячи зі штатного розпису, в школі налічувались 31 викладач першої категорії (класу), 10 другої, 7 - третьої та 10 представників військової адміністрації на чолі з Б. Сарреттом, дев'ять 3 яких мали військові звання (Pierre, 1900: 85). Аналізуючи поіменний список викладацького й адміністративного складу школи, неважко помітити, що більшість із них представляли відомі музиканти паризьких театрів (Ф. Дев’єн, А. Юго, Ж. Лефевр, Ф. Дюверн, Е. Озі й інші), а також авторитетний композитор Ф. Госсек, котрий ще продовжував залишатись очільником Королівської школи співу й декламації. У цьому переліку ім'я керівника закладу капітана Б. Сарретта залишалось найменш відомим.

Сформований під революційними знаменами колектив складали авторитетні музиканти, окремі 3 котрих (Ф. Госсек, С. Катель, І. Блазіус, Е. Озі, М. Гебауер, Ф. Дев'єн) не були в захваті від революційних ідей і непередбачуваної політики нової влади (Jardin, 2006: 44). Однак, намагаючись зберегти свій високий професійний статус і власну фінансово-економічну стабільність, вони були готові до пошуків із метою створення ефективної системи музичної освіти, котра б гарантувала високий рівень підготовки виконавців. Під впливом своїх досвідченіших колег Б. Сарретт прагне розширити список інструментальних класів школи, обмежених раніше лише духовими інструментами, й доповнює їх струнними, фортепіано й вокалом.

Подібний запит на необхідність створення широкопрофільного навчального музичного закладу 3 включенням всіх виконавських спеціальностей виникає й в загальносуспільній думці. Громадськість, схвалюючи зусилля Національної гвардії «для підтримки й пропаганди свого мистецтва, $<\ldots>$ де грають лише на духових інструментах», одночасно звертає увагу на відсутність «закладів, де також можна вдосконалити мистецтво співу й струнних інструментів ${ }^{4}$. Такий заклик спільноти виглядає цілком природно, враховуючи те, що на четвертому році революційних реформ і перенасиченості вуличними маніфестаціями й всенародними святкуваннями 3 традиційним супроводом духових оркестрів Національної гвардії вже відчувалась потреба в більшому урізноманітненні культурно-видовищних заходів i виконавських колективів.

Не дивлячись на те, що наступна спроба Б. Сарретта щодо створення музичного навчального закладу вищого рівня - Національного музичного

${ }^{4}$ Chronique de Paris, 10 janvier 1793, p. 40. Цит. за (Pierre, 1900: 85). 
інституту, - ще не отримала одностайної підтримки через наявні фінансові труднощі уряду, його активні дії продовжуються. Серед аргументів, які висуває Сарретт, звучить також і патріотична тема: «Наші деспоти, які не вміли скористатися французьким генієм, пішли шукати митців у німців. Під час правління свободи їх слід знайти серед французів» (Pierre, 1900: 89). Ці слова були спрямовані проти «засилля застарілої та деспотичної моделі вокального й інструментального навчання» Німеччини й Італії (Jardin, 2006: 44), яка існувала за часів правління короля.

Зазначимо, що активізація діяльності Б. Сарретта та його однодумців із метою створення Національного музичного інституту відбувається в надзвичайно складний час політичних потрясінь. Період Великого терору в боротьбі проти «ворогів народу» й закон про «підозрілих» дозволяв без цивілізованого судочинства на основі доносів арештувати будь-кого й виносити лише два вироки - свобода або смерть. Не вдалось уникнути участі «підозрілого» й Б. Сарретту, який своїми реформаторськими поглядами й активними діями викликав заздрість в опонентів. Донос 3 обвинуваченнями його в змові з аристократами й у тероризмі (Pierre, 1895: 64) міг стати для нього фатальним. Однак рішучі дії колег на захист свого очільника дозволили йому після короткого ув'язнення уникнути незаконного переслідування та продовжити свою діяльність.

Не дивлячись на політичну нестабільність i фінансово-економічні труднощі, наполегливість Б. Сарретта дала можливість реалізувати, хоча й не в повному обсязі, основні плани щодо створення музичного навчального закладу вищого рівня професійної підготовки виконавців. У листопаді 1793 р. Конвентом було прийнято рішення про відкриття Національного музичного інституту на базі музичної школи Національної гвардії. На честь знаменної події була організована зустріч учнів і викладачів із представниками влади й відбувся великий концерт ${ }^{5}$, метою якого стала демонстрація талантів, покликаних впевнено представляти національне мистецтво (Pierre, 1900: 92).

Затверджений указ щодо реорганізації музичної школи Національної гвардії в Національний музичний інститут давав змогу новому навчальному закладу не тільки збільшити штат на 13 викладачів, але й додатково включити навчання

\footnotetext{
5 До програми концерту були включені: Увертюра й Патріотичний гімн для духового оркестру С. Кателя, Salutaris, Похоронний марш, Симфонія для 11 духових Ф. Госсека, Концертна симфонія для флейти, гобоя, фагота й валторни Ф. Дев'єна й Тріо для 2-х кларнетів і фагота К. Лефевра (Pierre, 1900: 92).
}

на струнних інструментах (скрипка, віолончель, контрабас). Таким чином, зусилля Б. Сарретта значною мірою увінчались успіхом. Його наполегливість у намаганні досягти повної реалізації раніше наміченого плану спонукає залучити до цього процесу також Ф. Госсека, щоб об’єднаними зусиллями «створити інституцію, яка зможе конкурувати 3 європейськими центрами музичної підготовки фахівців (особливо німецькими й італійськими)» (Jardin, 2006: 44).

Глибока професійна обізнаність Ф. Госсека в царині музичної освіти, котрий як колишній директор Королівської академії співу й декламації був надзвичайно зацікавлений у реорганізації нещодавно відкритого Національного музичного інституту й об'єднанні обох навчальних закладів в єдиний центр французької музики, разом із революційними ідеями патріотично мотивованого Б. Сарретта не могли залишити членів Конвенту байдужими до назрілих проблем формування національної системи музичної освіти із центром у столиці. Тим більше, що зникнення з культурномистецького ландшафту метриз вимагало негайного заповнення порожнечі. У своїх петиціях Б. Сарретт і Ф. Госсек звертають увагу членів Конвенту на необхідність створення головного музичного навчального закладу, в якому через об'єднання Національного музичного інституту й Королівської академії співу й декламації були б представлені всі виконавські спеціальності.

У підготовленому проєкті реорганізації двох музичних навчальних закладів, виголошеному в проникливій доповіді драматурга М.-Ж. Шеньє Центральний музичний інститут ${ }^{7}$ подається як зразкова модель не наявної на той час в Європі музично-освітньої установи, абсолютно нової за структурно-адміністративним устроєм і художньо-педагогічним змістом процесу підготовки «дорогоцінних талантів» (Pierre, 1900: 120). 3 серпня 1795 р. Конвент, заслухавши звіт своїх комітетів із питань державної освіти й фінансів,

\footnotetext{
${ }^{6}$ Шеньє Марі-Жозеф(1764-18 11 рр.) - французький драматург і політичний діяч. Його творчість як драматурга відрізняється жанровою різноманітністю. До окремих п'єс Шеньє Мегюлем і Госсеком була написана музика, в якій особливою популярністю користувалась “Chant du Départ' (1794р.), котра стала народною піснею. Як обраний член Конвенту, М.-Ж. Шеньє брав активну участь у законотворчій діяльності й був автором законів у сфері мистецтва й народної освіти.

${ }^{7}$ Така назва закладу пропонувалась спочатку, згодом була використана інша - Національний інститут музики. Однак пізніше, як стверджував Б. Сарретт, «П. К. Дону попросив мене віддати йому назву «інститут», котра знадобилося для майбутнього Національного інституту наук і мистецтв (одного 3 трьох підрозділів Академії наук). Я відчув важливість прохання та попросив Шеньє замінити слова «інститут» на «консерваторію» як вказівку на мету цього закладу» (Pierre, 1900: 123).
} 
приймає указ про відкриття консерваторії «для виконання та викладання музики». Таким чином було успішно завершено процес народження на теренах Франції музичного навчального закладу нового типу. За задумом іiі творців, він повинен був стати не тільки взірцем для формування муніципальних консерваторій, але й головною музично-методичною установою, яка б очолила процес становлення та розвитку демократичної системи професійної музичної освіти. Саме такі ідеї звучать у наступних проєктах реформаторів $^{8}$, котрі пропонують докорінну перебудову підготовки професійних музикантів і створення трирівневої системи навчальних музичних закладів, на вершині якої повинна була знаходитись Паризька консерваторія, наділена певними адміністративно-контрольними функціями.

Найскладнішим i найважливішим питанням для новоствореного закладу стало отримання державного фінансування, яке гарантувало матеріально-фінансове забезпечення навчального процесу в цілому й студентсько-викладацького колективу зокрема. Такий пункт був чітко прописаний у законопроєкті: «Витрати на адміністрування та утримання консерваторії регулюються та уповноважуються виконавчою владою, згідно із заявами адміністрації консерваторії; ці витрати оплачує Державне казначейство» (Pierre, 1900: 124).

В Європі на той час неможливо було відшукати музичний навчальний заклад, в якому могли навчатись безплатно 600 студентів під керівництвом 115 викладачів. Не дивлячись на те, що приєднання Королівської академії співу й декламації та розширення профільних спеціалізацій (вокал, клавесин, композиція) сприяли більшій академізації та класичному спрямуванню процесу підготовки фахівців, ідеологічна складова частина в навчальних програмах продовжувала зберігатись. Консерваторія повинна була забезпечувати навчання музикантів для служби в оркестрі Національної гвардії, брати активну участь у державних урочистостях і проведенні масових політично-ідеологічних заходів. Серед студентів і професорів пріоритет залишався за виконавцями на духових інструментах, які становили $54 \%$ всього колективу консерваторії 9 (Jardin, 2006: 46).

\footnotetext{
${ }^{8}$ П. К. Дону (1796 р.), Ж. Б. Леклерк (1798 р.), Б. Сарретт (1801 р.).

${ }^{9}$ Серед них найчисельнішими були класи: кларнета - 19 , фагота - 12, валторни - 12; менша кількість спостерігалась у флейт -6 , гобоїв -4 , серпентів -4 , труб - 2 ; у тромбона, туби й букцини - тільки по одному класу (Jardin, 2006: 46) Що стосується інших спеціальностей, то розподіл був таким: 8 класів скрипки, 4 - баса, 1 - контрабаса; 6 - клавесина, 1 органа; 9 - вокалу; 14 - теорії (сольфеджіо) і 7 - композиції (Pierre, 1900: 125).
}

Засадничим принципом формування педагогічного й студентського складу консерваторії була затверджена в статуті конкурсна система прийому. На конкурсній основі приймались всі студенти й викладачі, строгий відбір яких проводила спеціальна комісія, створена 3 найавторитетніших музикантів. Викладачі консерваторії відповідно до рівня професійної майстерності розділялись на три класи (категоріі). Усього для педагогічного складу навчального закладу було виділено 28 посад професора ${ }^{10} 1$ класу, $54-2$ класу й 28 - третього ${ }^{11}$.

Для належного забезпечення навчального процесу науково-методичними матеріалами викладачі консерваторії повинні були створювати дидактичні посібники (школи) для окремих інструментів і підручники з теоретичних дисциплін. Зазначимо, що, крім підготовки професійних музикантів, у консерваторії здійснюються спроби організації окремого наукового підрозділу - кафедри акустики ${ }^{12}$ для провадження науково-дослідницьких робіт. Таким чином, Сарретт зі своїми однодумцями створює новітню за формою та змістом модель навчального закладу, за зразком якого в майбутньому буде розвиватись не тільки національна система музичної освіти Франції, але і Європи в цілому.

Висновки. Розглядаючи етапи формування французької музично-освітньої системи кінця XVIII ст. і передумови створення Паризької консерваторії, необхідно виділити визначальну роль Великої французької революції, яка стала початком корінної перебудови соціально-економічного й політичного устрою суспільства й мала вирішальний вплив на розвиток музичного мистецтва. Орієнтир на вулично-маніфестаційну спрямованість музики та іiі доступність для широких мас одночасно зі зламом старої системи метриз, у результаті чого виникла порожнеча в культурномистецькому просторі, вимагали створення необхідної музично-освітньої інфраструктури, котра б забезпечувала «служіння мистецтва революційним ідеалам». 3 обранням духового оркестру Національної гвардії на чолі з Б. Сарретом основними провідниками нової музично-культурної доктрини починається процес формування загаль-

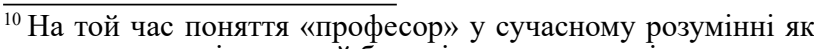
вчене звання не існувало й було рівнозначне назві «викладач» будь-якого навчального закладу.

11 Посадовий оклад викладача першого класу становив 2500 ліврів, другого - 2000 і третього - 1600 (Pierre, 1900: 125).

12 Така пропозиція до нижньої палати законодавчих зборів (Ради п’ятисот) поступила від одного 3 представників Інституту наук і мистецтв 22 вересня 1795 р., однак не отримала одностайної підтримки скоріш за все через брак фінансових коштів (Pierre, 1900: 127).
} 
них контурів майбутньої системи підготовки професійних музикантів, першою ланкою якої стала військово-музична школа.

За короткий час Б. Саррету разом із досвідченими й авторитетними паризькими музикантами, не дивлячись на політичний тиск та економічну нестабільність, вдалось започаткувати новий музично-освітній заклад, основними перевагами котрого стали демократичний доступ до навчання, державне фінансування, конкурсна система формування професорсько-викладацького й студентського колективу, широке охоплення практично всіх музичних спеціальностей. Таким чином, Паризька консерваторія як навчальна музична установа нового типу в майбутньому стала зразком для багатьох європейських країн.

\section{СПИСОК ВИКОРИСТАНИХ ДЖЕРЕЛ}

1. Подмазова П. Б. Французское классическое скрипичное искусство и Парижская консерватория. Вестник МГУКИ. 2013. № 2. С. 242-245.

2. Радиге А. Французские музыканты эпохи Великой французской революции / пер. с франц. Г. М. Ванькович, Н. И. Игнатовой ; ред. М. В. Иванов-Борецкий. Москва : Музгиз, 1934. 165 с.

3. Bodin J. L. Q. L'orchestre de la Sociétè Olympique en 1786. Revue de Musicologie. 1984. T. 70. No. 1. P. 95-107.

4. Dean W. Opera under the French Revolution. Proceedings of the Royal Musical Association. 1967-1968. 94th Sess. P. 77-96.

5. Dratwicki A. La rèorganisation de l'orchestre de l'Opèra de Paris en 1799: De nouvelles perspectives pourle rèpertoire de l'institution. Revue de Musicologie. 2002. T. 88. No. 2. P. 297-325.

6. Holoman D. K. The Paris Conservatoire in the Nineteenth Century. Oxford Handbooks. 2015. URL: https://www.oxfordhandbooks.com/view/10.1093/oxfordhb/ 9780199935321.001.0001/oxfordhb-9780199935321-e-114.

7. Holoman D. K. The Société des Concerts du Conservatoire, 1828-1967. Berkley and Los Angeles, CA : University of California Press, 2004. 636 p.

8. Jardin Etienne. Le conservatoire et la ville : les écoles de musique de Besançon, Caen, Rennes, Roubaix et SaintÉtienne au XIXe siècle. Thèse de doctorat, Paris, EHESS, 2006. 651 p.

9. Lassabathie Th. Histoire du Conservatoire impérial de musique et de déclamation. Paris : Michel Lévy Frères, 1860. $572 \mathrm{p}$.

10. Maurat E. L'enseignement de la musique en France et les conservatoires de Province. Encyclopédie de la musique et dictionnaire du conservatoire / A. Lavignac, L. de la Laurencie. Deuxième partie. Paris : Delagrave, 1925. P. 3575-3616.

11. Pierre Constant. Le Conservatoire national de musique et de declamation: documents historiques et administratifs. Paris : Imprimerie nationale, 1900. 1031 p.

12. Pierre Constant. B. Sarrette et les origines du Conservatoire national de musique et de déclamation. Paris : Delalain frères, $1895.196 \mathrm{p}$.

\section{REFERENCES}

1. Podmazova P. B. Frantsuzskoye klassicheskoye skripichnoye iskusstvo i Parizhskaya konservatoriya [The French Classic Violin Art and the Paris Conservatory]. Vestnik MGUKI, 2013. № 2. S. 242-245. [in Russian].

2. Radige, A. (1934). Frantsuzskiye muzykanty epokhi Velikoy frantsuzskoy revolyutsii [The French Musicians of the Great French Revolution Age]. (Trans. G. M. Van'kovich, N. I. Ignatovoy). M. V. Ivanov-Boretskiy (Ed.). Moscov: Muzgiz. 1934. 165 s. [in Russian].

3. Bodin, J. L. Q. L'orchestre de la Sociétè Olympique en 1786. Revue de Musicologie, 1984. T. 70. No. 1. P. 95-107.

4. Dean, W. Opera under the French Revolution. Proceedings of the Royal Musical Association. 94th Sess, 1967-1968. P. 77-96.

5. Dratwicki, A. La rèorganisation de l'orchestre de l'Opèra de Paris en 1799: De nouvelles perspectives pourle rèpertoire de l'institution. Revue de Musicologie. 2002. T. 88, No. 2. P. 297-325.

6. Holoman, D. K. The Paris Conservatoire in the Nineteenth Century. Oxford Handbooks. 2015. https://www.oxfordhandbooks.com/view/10.1093/oxfordhb/ 9780199935321.001.0001/oxfordhb-9780199935321-e-114.

7. Holoman, D. K. The Société des Concerts du Conservatoire, 1828-1967. Berkley and Los Angeles, CA: University of California Press, 2004. 636 p.

8. Jardin Etienne. Le conservatoire et la ville : les écoles de musique de Besançon, Caen, Rennes, Roubaix et SaintÉtienne au XIXe siècle. Thèse de doctorat, Paris, EHESS. 2006. 651 p.

9. Lassabathie, Th. Histoire du Conservatoire impérial de musique et de déclamation. Paris: Michel Lévy Frères, 1860. $572 \mathrm{p}$.

10. Maurat, E. L'enseignement de la musique en France et les conservatoires de Province. Encyclopédie de la musique et dictionnaire du conservatoire. A. Lavignac, L. de la Laurencie. Deuxième partie. Paris: Delagrave, 1925. P. 3575-3616.

11. Pierre, Constant. Le Conservatoire national de musique et de declamation: documents historiques et administratifs. Paris: Imprimerie nationale, 1900. 1031.

12. Pierre, Constant. B. Sarrette et les origines du Conservatoire national de musique et de déclamation. Paris : Delalain frères, $1895.196 \mathrm{p}$. 